UNIVERSIDADE DE SÃO PAULO

ESCOLA DE EDUCAÇÃO FÍSICA E ESPORTE

\title{
EFEITOS DO USO DE ESTERÓIDES ANABOLIZANTES ASSOCIADOS AO TREINAMENTO FÍSICO DE NATAÇÃO SOBRE O FLUXO SANGÜÍNEO PARA O MIOCÁRDIO DE RATOS NORMOTENSOS
}

Fernanda Roberta Roque Redondo

SÃO PAULO

2007 